\title{
The urban-rural divide in radical right populist support: the role of resident's characteristics, urbanization trends and public service supply
}

\section{Jonna Rickardsson ${ }^{1}[$}

Received: 22 November 2018 / Accepted: 4 January 2021 / Published online: 12 February 2021

(c) The Author(s) 2021

\begin{abstract}
In a number of recent elections in Western Europe, support for far-right populist parties has been significantly higher in non-urban areas than in urban areas. This paper answers the following questions; (1) Can the urban-rural divide in voting behavior be explained by the fact that urban and non-urban populations differ in terms of education, income and other individual characteristics of voters, or by variations in immigration? (2) Can variations in public service supply explain parts of the urbanrural divide in far-right populist support? and (3) How does population growth and public services relate to voting behavior when examining urban and rural municipalities separately? The analyses combine survey data on individual characteristics and register data aggregated on municipalities. The results in this paper suggest that voter characteristics and immigration explain a substantial part of the urban-rural divide. However, the propensity to vote for a far-right populist party is still higher in regions with lower population growth even when controlling for individual characteristics and immigration. When considering public service supply, the urban-rural divide is further weakened. The propensity to vote for a far-right party decreases with higher public service supply and higher share of immigrants. The findings in this paper thereby support the hypothesis that individuals in shrinking areas with lower access to public services are likely to respond to the deterioration of their location by casting a vote on the far-right (i.e., protest voting).
\end{abstract}

Keywords Political economics · Regional economics · Urbanization · Public services $\cdot$ Voting behavior $\cdot$ Populism $\cdot$ Extreme right $\cdot$ Radical right

JEL Classification $\mathrm{D} 72 \cdot \mathrm{H} 41 \cdot \mathrm{H} 75 \cdot \mathrm{O} 18 \cdot \mathrm{R} 11 \cdot \mathrm{R} 23$

Jonna Rickardsson

jonna.rickardsson@ju.se

1 Jönköping International Business School (JIBS), Centre for Entrepreneurship and Spatial Economics (CEnSE), Jönköping University, Box 1026, 55111 Jönköping, Sweden 


\section{Introduction}

The trend of urbanization continues to permeate throughout the world causing differences between urban, non-urban and rural areas to accelerate. Recently, these differences have shown to have strong influences on election outcomes, with a large overrepresentation of voters in rural areas over urban areas in favor of candidates like Marie Le Pen (Politico 2017) and Donald Trump (Cramer 2017), and issues such as Brexit (Beckett 2017). In Sweden, not only did voter support for the Sweden Democrats differ between urban areas and non-urban areas (Mellander et al. 2014), but confidence in the national Swedish government also differed (Arkhede and Oscarsson 2016). The research examining this urban-rural divide in voting behavior is limited.

As a converse effect of urbanization and agglomeration, non-urban areas are subject to (1) higher unemployment rates, (2) lower education and (3) lower income levels. They also tend to have (4) lower shares of immigrants. These four factors are what the majority of prior literature on radical right populist support has found to relate to voting behavior (see, for example, Antonucci et al. 2017; Hobolt 2016; Lee et al. 2018; Rydgren and Ruth 2011, 2013). Since these determinants of far-right support vary substantially between urban and non-urban areas (e.g., in terms of the composition of urban and non-urban populations), one might not be very surprised by an urban-rural divide in far-right populist support. But do these socioeconomic determinants, alone, adequately explain the variation in support for the populist radical right ${ }^{1}$ across urban and non-urban regions? Or, alternatively, does depopulation and its cascade of consequences relate to support for these parties even when individual characteristics and immigration are controlled for? As people increasingly leave rural places, total demand decreases, which sequentially results in weaker labor markets and shutdowns of important public and private services (Bjerke and Mellander 2016). Recently, shutdowns of public establishments and services in nonurban areas as well as increasing geographical inequality have received great attention in the public debate in Sweden. While the income tax rates generally are higher in non-urban municipalities, the availability of services is lower. The lower access to public services in declining rural areas could be a contributing explanation for the map of populist support and political dissatisfaction. Therefore, this paper also tests whether availability of — and satisfaction with — public services is related to far-right populist support.

This paper examines the relationship between urbanization, proxied by (1) an urban versus non-urban categorization of Swedish municipalities ${ }^{2}$ (approximately equivalent to an American county) and (2) population growth, and voting behavior by combining survey data on individual characteristics and register data aggregated on municipalities. The following three questions are asked; (1) Are urban status or urban trends related to support for the Swedish far-right populist

\footnotetext{
1 In this paper, the terms "radical right populist," "far-right populist" and "extreme right populist" are treated as synonymous.

2 See "Appendix" for the categorization of municipalities as urban or non-urban.
} 
party, the Sweden Democrats, when controlling for individual characteristics of the voter and immigration? (2) How does availability of public services relate to the urban-rural divide in support for the Sweden Democrats? And (3) Do the relationships between population growth, public services, and support for the Sweden Democrats vary between urban and non-urban municipalities?

The findings in this paper show that the relationship between urbanization proxies and support for the Sweden Democrats weakens substantially when controlling for individual characteristics of voters, but that voting behavior still varies significantly between urban and non-urban municipalities and with population growth. Hence, the findings in this paper establish that the urban-rural divide in support for the party cannot be fully explained by variations in population composition in terms of, e.g., income, education, unemployment. There are additional factors linked to urbanization (and conversely, to depopulation of non-urban areas) that explain the party support gap between denser and less dense areas. When controlling for immigration, the relationship between urban status and support for the Sweden Democrats weakens further and becomes insignificant. A higher share of immigrants in the region significantly decreases the likelihood of casting a vote for the Sweden Democrats, and urban areas have higher shares of immigrants than rural areas. The relationship between population growth and Sweden Democrat support stays significant and negative when immigration is added to the model, suggesting that population trends and regional development matters more than urban status for resident's likelihood of supporting the Swedish radical right.

Considering public service supply (e.g., school services, health care services), the relationship between Sweden Democrat support and urbanization trends either reduces substantially or becomes insignificant. A larger supply of (and satisfaction with) public services decreases the probability of voting for the Sweden Democrats substantially. It is, however, difficult to establish a causal link from access to/satisfaction with public services to voting for the populist far-right, since the level of public services provided may be both a cause and a result of depopulation and economic decline (the bias decreases, however, since economic factors like income and unemployment are controlled for). Nevertheless, the results suggest that public services play an important role for far-right populist support, especially in non-urban areas. These results are indications that the role of public services and shutdowns of public establishments on far-right populist support needs to be further examined using better identification strategies.

This paper contributes to the existing strand of literature in numerous ways. While there is a growing number of studies examining the determinants of populist support, none of them looks at the relationship between urbanization and voting behavior explicitly nor do they consider the potential role of public services. This paper emphasizes that the urban-rural divide in far-right populist support not only arises from immigration or economic factors such as employment status and income, but that other regional characteristics, like public services, which vary between urban and non-urban areas (or growing and shrinking areas), also matter. 


\subsection{Background and motivation}

During the last fifty years, far-right populist parties have increasingly reemerged and gained an expanding electoral support across Western Europe, as well as in other parts of the world (e.g., Canada and Australia). While far-right parties have long had only marginalized support in Sweden, in recent years the anti-immigration party, the Sweden Democrats, has received increasingly strong electoral support and parliamentary seats. The Sweden Democrats is the Swedish version of the more global phenomena of radical right and populist parties growing (see, for example, Dal Bó et al. 2018; Dehdari 2018; Oskarson and Demker 2015, Rydgren and Ruth 2011, 2013, Strömblad and Malmberg 2016). The party received $2.9 \%$ of the votes in the 2006 election, $5.7 \%$ of the votes in the 2010 election, and $12.9 \%$ of the votes in the 2014 election, an increase by $126 \%$ over the previous election. The Sweden Democrats are now Sweden's third largest parliamentary party. With its roots in former right-wing extremist and racist parties (Rydgren 2010), today the party presents itself as a nationalistic and conservative party (Sverigedemokraterna 2017). The party is critical toward the "multicultural" society, which it considers threatening to the national heritage and the Swedish culture (Sverigedemokraterna 2017). Therefore, the party advocates severely restricted immigration. Additionally, the Sweden democrats wants Sweden to renegotiate its EU-membership for a more EEA-like (European Economic Area) membership.

Sweden consists of 290 municipalities that vary substantially in terms of area, population density and population growth. The support for the Sweden Democrats increased in all municipalities between the elections 2010 and 2014, but there is a large variation in election support for the party across municipalities. The vote outcome for the Sweden Democrats in the election 2014 varied between 5.3\% and $29.9 \%$ amongst the Swedish municipalities. The geographical distribution of the party's vote outcome is illustrated in Fig. 1. The darker the red color in Fig. 1, the higher the vote support for the party in the 2014 election. The variation in population size stretches from small rural municipalities with fewer than 3000 inhabitants to dense metropolitan areas like Stockholm, Gothenburg and Malmö with more than 300,000 inhabitants. Figure 2 illustrates the population density in 2014 for Swedish municipalities (quantiles), where a darker blue color represents municipalities with a higher population density.

In Fig. 1, it is clear that the highest support for the Sweden Democrats is found in the municipalities in the very south of Sweden (the province of Skåne). The lowest support is found in the North and along the coastlines and in the municipalities around the two largest cities in Sweden (Stockholm and Gothenburg). Comparing Figs. 1 and 2, we can see that the lighter red areas in Fig. 1, which indicate high support for the Sweden Democrats, are most often matched by darker blue colors in Fig. 2 (low population density). Hence, municipalities that have a higher population density support the party to a smaller extent. Although this pattern is less clear in the very south and in the north, in the middle of Sweden (defined as shown in Fig. 3 in "Appendix"), where the great majority of the Swedish population resides (approximately 80\%), it is a quite clear mapping. 
Fig. 1 Support for the Sweden Democrats (\%) 2014

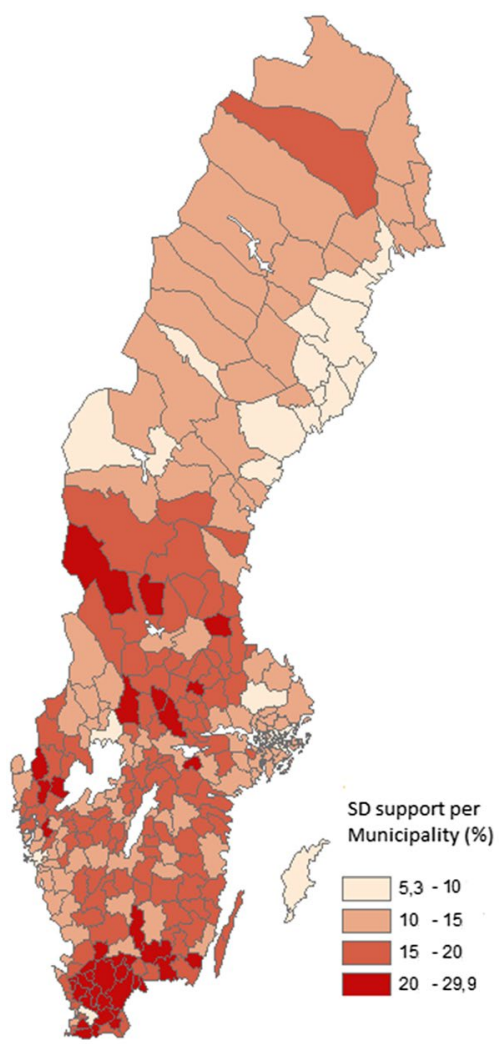

In the SOM-institute's survey data (explained more in depth later), approximately $15 \%$ of the respondents who answered that they voted for the Sweden Democrats in 2014 do not consider the party their favorite one (based on the question: which party is your favorite party?). Five percent of the Sweden Democrat voters prefer the Social Democrats (the largest left-wing party in Sweden) and four percent of them prefer Moderaterna (the largest right-wing party in Sweden). Furthermore, 38\% of the Sweden Democrat voters in the survey do not consider themselves to be convinced supporters (while $37 \%$ of the Sweden Democrat voters consider themselves to be somewhat convinced supporters, and $25 \%$ convinced party supporters).

\section{Regional dynamics and voting behavior}

\subsection{Geography of voting behavior and regional development}

Regional development and the well-being of regions have received great attention both from researchers and politicians. There is a large body of literature that covers the effects of agglomeration economies on regional development. Jacobs 
Fig. 2 Population density (quantiles) 2014

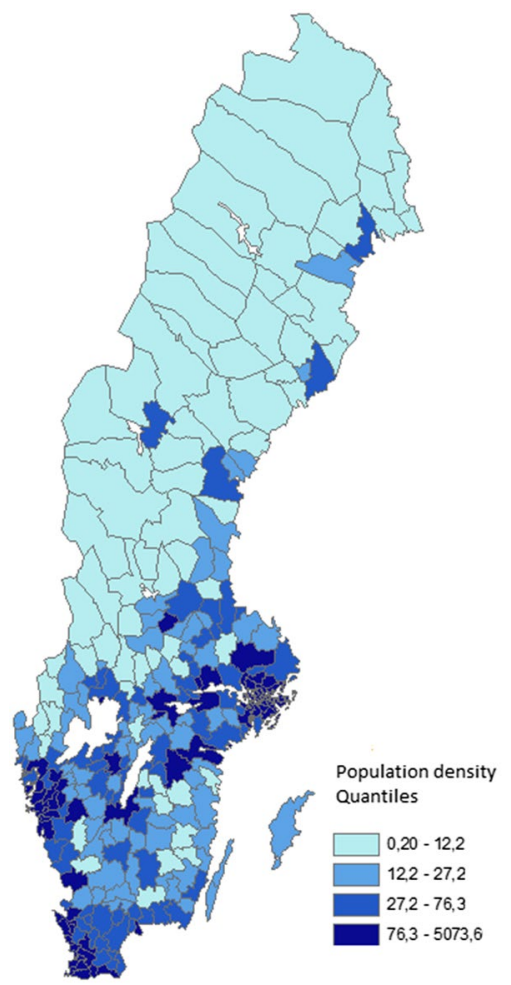

(1969) discusses the urbanization process to be one of the most important growthenhancing phenomena. In comparison with less dense areas, urban areas have an advantage in having greater access to diversity both in terms of individuals and industries/firms (Glaeser 2011; Karlsson et al. 2019). Transport costs are lower in cities (Glaeser et al. 2001); technology is better; ideas and knowledge travel faster across individuals and firms (Jacobs 1969); and labor market matching is more efficient (Marshall 1890) - all inducing productivity in cities (Duranton and Puga 2004). But urban cities do not attract individuals solely through stronger labor markets, productivity and growth, but also because they can offer their residents greater consumption possibilities with a larger variety of both consumer goods and services, shorter commuting times, and more accessible public services [see for example Glaeser et al. (2001) and Florida (2002)]. Urban areas are also found to be more tolerant and open toward minority groups than rural areas (Florida 2002), a factor expected to help explain why individuals with immigrant backgrounds are more likely to reside in urban regions than Swedish born natives (Bjerke and Mellander 2016). 
Non-urban municipalities benefit a lot less from agglomeration and urbanization effects. ${ }^{3}$ As a result of urbanization, the population size in rural areas has often been declining. Government interventions have so far failed to turn around or even slow down this trend. It is primarily young individuals who are leaving rural municipalities, many of whom move away to go to university or college and then do not return. This leads to an aging remaining population and weaker labor markets (Mellander 2013).

Demographic changes of this kind also have large effects on non-urban municipalities' revenues. Smaller and continuously declining areas with a falling share of the population in working-age experience smaller and diminishing tax bases. In Sweden, local income tax accounts for, on average, $60 \%$ of a municipality's total revenues (Bergström et al. 2004). Hence, service provision will heavily depend on local tax incomes which in turn is determined by urbanization trends. ${ }^{4}$ Although struggling municipalities receive government funds through the so called equalization scheme, ${ }^{5}$ to account for the large demographic differences, tax rates are generally higher in non-urban and rural municipalities than in urban municipalities. And as people increasingly move from non-urban to urban areas, providing the same amount of public services in non-urban areas becomes more expensive (e.g., establishments, specialized services) (SOU 2015). As population decreases, the demand for local features such as shops and services, schools and health facilities in these areas decline as well. Decreasing municipal revenues and lower demand leads to a subsequent decrease in supply of services and shutdowns of important public functions. This results in a worsening quality of life in rural areas over time (Bjerke and Mellander 2016). Also, unemployment rates are higher in rural areas than in urban areas, although the gap has been decreasing for some time (The Board of Agriculture 2013).

Based on Tiebout's model, we would expect most people to leave rural/non-urban places as tax-public goods packages become less attractive. Worsening public service provision and hence lower utility are likely to generate political dissatisfaction. ${ }^{6}$ However, while some dissatisfied individuals move in accordance with Tiebout's theory, many individuals stay, suggesting that the model may overestimate the mobility of individuals or underestimate the strength of connection to one's municipality. Hirschman's theory on exit, voice, and loyalty offers more options

\footnotetext{
3 Non-urban municipalities in Sweden are heterogeneous, and while most of them have seen a decline in population, others have not. Klaesson and Pettersson (2009), for instance, show that non-urban municipalities with close access to larger cities have a higher rate of development of population and employment than other non-urban municipalities.

4 Swedish municipalities and/or counties set their own income tax rate and decide on public service provisions but the prices of various public services (e.g., medical consultation, children care, etc.) are decided by the national government and are the same across Sweden's municipalities.

5 There is a regional equalization scheme in Sweden, and struggling municipalities receive government funds but distances to public services still increase due to shutdowns and/or mergers of public establishments.

${ }^{6}$ Since the key variation in price for public services across municipalities is the transportation cost, an individual's utility of public services depends on the geographical distance to these services (Hotelling 1929).
} 
(Hirschman 1970). Residents can choose either to move to a more prosperous and promising location (exit, i.e., vote with their feet), or stay and try to influence the regional development trend (voice), but with the risk of sinking with the ship in a place lacking future prospects. It is reasonable to assume that the individuals who stay in deteriorating municipalities will voice their dissatisfaction in other ways-for instance, by protest voting for a radical right populist party, e.g., against the ruling party (party coalition/the establishment).

Individuals can decide to vote for a radical right populist party in order to show discontent. Van der Brug et al. (2000) argue that protest voting is a rational activity motivated by a wish to show dissatisfaction with existing political leadership and direction. A common definition of the concept of protest voting consists of two elements; (1) a strong relationship between radical right support and dissatisfaction with ruling parties and politicians due to a lack of political trust and (2) a sense that political attitudes are of minor importance for these voters (Van der Brug and Fennema 2007). Hence, per definition, a protest vote is not strictly based on ideological and pragmatic considerations, or on sympathy for the party's policy objectives (for example their anti-immigration standpoints), but it is rather a vote against other parties and their policy or absence of policy.

In accordance with the protest-vote theory discussed above, Lee et al. (2018) find immobile people_-proxied as individuals living in their county of birth — to be more likely to be in favor of Brexit, especially if they live in places experiencing relative economic decline or that have seen a large increase in non-white migration. Rodríguez-Pose (2018) discusses Brexit support as an activity of "revenge of the places that don't matter" and that the deterioration of rural regions is likely to generate political dissatisfaction. Other research has found political dissatisfaction (Ford and Goodwin 2010; Lubbers et al. 2002; Lubbers and Scheepers 2002) as well as dissatisfaction with the EU and democracy (Arzheimer 2009) to be strongly related to radical right populist support.

Thus, one argument is that populism is a response to economic decline and dissatisfaction, but another well-established argument to explore is that the rise in populism is a reaction against increasing immigration. However, while the most common self-reported reason for radical right voting is anti-immigration attitudes (Ivarsflaten 2008; Oesch 2008), it is still not clear whether exposure to immigrants triggers these sentiments or not. According to conflict theories, immigration is expected to increase far-right populist support as higher immigration levels increase conflict over scarce resources, like low-skilled jobs and subsidies, and takes up a larger portion of the available tax-fund (Belanger and Pinard 1991). But higher shares of immigration can also decrease far-right support as interethnic interaction decreases prejudices (contact hypothesis) (Allport 1954/1979). While previous within-country research is ambiguous, the vast majority of studies find a positive relationship between the proportion of immigrants and radical right-wing support on a micro-level (Coffé et al. 2007; Ford and Goodwin 2010; Lubbers and Scheepers 2002; Rydgren and Ruth 2011, 2013). A few studies find no relationships (see for example Dal Bó et al. 2018; Kestilä and Söderlund 2007; Rydgren and Ruth 2013; 
Westinen 2014). ${ }^{7}$ Recent inflow or growth in the rate of immigration is found to be positively related to support for Brexit (Goodwin and Milazzo 2017) and to growth in municipal support for the Sweden Democrats between the Swedish elections 2010 and 2014 (Wennström and Öner 2015).

\subsection{Individual factors and radical right and populist support}

In rational choice theory, individuals act rationally and vote for parties that best take care of their interests. Driven by rationality, xenophobia and populist support can be the result of a conflict/competition between lower-class natives and immigrants over scarce resources (e.g., low-paid jobs, welfare benefits) (Esses et al. 1998). ${ }^{8}$ Conflict occurs, in particular, with native groups who are more exposed to enlarged competition from increasing immigration, in particular low-income, low-educated individuals.

Previous empirical research conducted on individual data find employment status, age, education, income and gender to relate to far-right and populist support (e.g., Arzheimer 2009; Arzheimer and Carter 2006; Ford and Goodwin 2010; Gidengil et al. 2005; Gordon 2018; Hobolt 2016; Lee et al. 2018; Lubbers and Scheepers 2002; Weakliem 2002). The vast majority of this research has been conducted on aggregated regional or country data and thus does not include individual characteristics. An important limitation with this empirical approach is that when examining only aggregated data, one cannot conclude whether individual factors and/or contextual factors (regional/neighborhood effects) matter. The support for theories on ethnic conflicts/competition in these cross-regional/cross-country studies varies. Among the aggregated factors that have been found to relate to far right or populist support are average income, unemployment rate, and education level (e.g., Coffé et al. 2007; Ford and Goodwin 2010; Rydgren and Ruth 2011, 2013). Also, economic decline, measured by wage growth, is found to be related to populist support (Brexit) (Lee et al. 2018).

The contributions of this paper are twofold. Firstly, the paper examines the relationship between urbanization and voting behavior more explicitly by exploring how Sweden Democrat support varies with urban status and urban trends, and to what extent this urban-rural voting gap can be explained by differences in population composition (i.e., by resident characteristics like education, income, gender, age, etc.). Separate analyses for urban and non-urban sub-samples are also conducted. Secondly, the paper examines whether public service provision can explain part of the urban-rural divide in Sweden Democrat support.

\footnotetext{
7 Rydgren and Ruth (2013) find a positive relationship between the proportion of immigrants from the Nordic countries and from EU/EFTA, but a negative relationship between the share of non-European immigrants and extreme right populist support (support for the Sweden Democrats).

${ }^{8}$ See also theories of Group Conflicts, going back to Sherif and Sherif (1953), and theories of Ethnic Competition (Belanger and Pinard 1991).
} 


\section{Research design}

\subsection{Data and identification strategy}

To answer the research questions, the analyses in this paper utilize survey data and register data combined, including approximately 5000 individuals. The geographic location for each individual is known, which allows for the inclusion of variables on population growth and immigration in the individuals' municipality. Sweden is divided into 290 municipalities with a population of, on average, 33,600 individuals (2014). The regional variables are based on register data from Statistics Sweden aggregated on municipalities, and on data from the Swedish Migration Agency. The survey data are collected from the survey "National SOM," which is a yearly survey conducted by the SOM Institute, Gothenburg University, since 1986. It consists of random samples of the Swedish population 16-85 years and is representative of the Swedish population for this age span (SOM-Institute 2015). The response rate in 2014 was approximately 55\%. More information on the survey construction, the data collection and the shortfall analysis can be found in the SOM report (Venersdotter 2015 ) or on the SOM Institute's website. ${ }^{9}$ To vote, one must be 18 years old; hence, younger individuals are excluded from the data. In similar fashion, individuals entitled to vote but who chose not to are excluded from the sample. In the 2014 election, the turnout was $86 \%$. In the survey data, only $3 \%$ of the respondents answered that they did not vote in the election 2014. While the Sweden Democrats received $12.9 \%$ of the votes in the 2014 election, in the survey sample, this number was $9.2 \%$. It seems reasonable that individuals who vote also are more likely to respond to the survey. Similarly, individuals who vote for the Sweden Democrats are either less likely to respond to the survey or less prone to admit their choice of party vote in the survey. ${ }^{10}$ Furthermore, in order to vote in the national election in Sweden, one has to be a Swedish citizen; hence, only Swedish citizens are included in the analysis.

\subsection{Empirical model and estimation}

The relationships between urbanization and public services and the propensity to vote for the Sweden Democrats are examined using a logistic regression approach. The dependent variable, $y_{i j}$, is binary and takes the value 1 if individual $i$ in municipality $j$ voted for the Sweden Democrats, and zero otherwise. The cumulative density function of the logistic distribution can be written as follows:

\footnotetext{
9 http://som.gu.se/som_institute/methodology.

10 The response rate is slightly lower for younger individuals and men, and the Sweden Democrats are particularly popular among young men. Thereby, the shortfall of Sweden Democrat voters is likely an effect of a small underrepresentation of young men (these patterns are seen in many survey data) (see Venersdotter 2015 for the figures). While this may result in a small bias, it would be a downward bias, i.e., an underestimation of the results.
} 


$$
\operatorname{Pr}\left(y_{i j}=1 \mid \boldsymbol{X}_{i j}\right)=\frac{\exp \left(2 \boldsymbol{X}_{i j}^{\prime} \boldsymbol{\beta}\right)}{1+\exp \left(2 \boldsymbol{X}_{i j}^{\prime} \boldsymbol{\beta}\right)}
$$

where $\operatorname{Pr}\left(y_{i j}=1 \mid \boldsymbol{X}_{i j}\right)$ is the probability that individual $i$ in municipality $j$ votes for the Sweden Democrats. $\boldsymbol{X}_{i j}$ is a set of explanatory variables describing individual and municipal characteristics for individual $i$, in municipality $j$. Adding the error term, $\varepsilon$, the estimated logit model can be specified;

$$
\operatorname{Logit}\left[\operatorname{Pr}\left(y_{i j}=1\right)\right]=\ln \left[\frac{\operatorname{Pr}\left(y_{i j}=1\right)}{1-\operatorname{Pr}\left(y_{i j}=1\right)}\right]=\alpha+\boldsymbol{X}^{\prime}{ }_{i j} \boldsymbol{\beta}+\varepsilon
$$

In order to simplify the interpretation of the results from the logistic regressions, these are presented in terms of odds ratios. Odds ratios show the ratio of the probability of voting for the Sweden Democrats over the probability of voting for any other party:

$$
\frac{\operatorname{Pr}\left(y_{i j}=1 \mid \boldsymbol{X}_{i j}+1\right)}{1-\operatorname{Pr}\left(y_{i j}=1 \mid \boldsymbol{X}_{i j}+1\right)} / \frac{\operatorname{Pr}\left(y_{i j}=1 \mid \boldsymbol{X}_{i j}\right)}{1-\operatorname{Pr}\left(y_{i j}=1 \mid \boldsymbol{X}_{i j}\right)}=\exp (\beta) .
$$

Clustered standard errors are used to correct for possible violations of independence between individuals in the same municipality, i.e., factors that do not vary across individuals in the same cluster but do vary across clusters.

\subsection{Variables}

The dependent variable Sweden Democrat support is based on the survey question Did you vote in the 2014 election and if so, for which party? The variable takes the value 1 if the respondent voted for the Sweden Democrats and the value 0 otherwise. The covariates consist of variables at two different levels: individual and regional. The variables of key interest are the two proxies for urbanization and the public service covariates.

The first urbanization proxy is the Urban dummy variable which is based on the categorization of municipalities into urban and non-urban/rural developed by the Swedish board of agriculture. This classification takes into account patterns of intramunicipal commuting, night population and population density. ${ }^{11}$ The second urbanization proxy is Growth in population density which measures the percentage growth in municipal population density between 2006 and 2010. The period 2006-2010 is chosen to avoid the large inflow of immigrants from 2011 onward (of which a large portion were placed in different municipalities not by choice but by the Migration

11 see "Appendix" for further explanation. 
Authority). The variable Growth in population density can act as an indication of how prosperous the municipality is-i.e., if it benefits from urbanization or not. ${ }^{12}$

A principal component analysis is conducted in order to create a Public Service variable. Included in this component is share of the municipal population working in (1) preschool and elementary school, (2) fire and rescue services, (3) primary health care services and (4) the police sector. The principal component is used as a proxy of total access to public services. The four public service components are also tested independently.

Since one common argument is that the populist vote is a vote against immigration, two variables on immigration are included: (1) Share of immigrants in the municipality, were immigrants refer to individuals born in countries other than Sweden, Denmark, Finland and Norway, and (2) Average municipal intake of refugees between 2010 and 2014, measured as the average increase in refugees as a share of the municipal population.

Two additional regional dummies are included-one for the municipalities located in the very south part of Sweden (South) and one for municipalities located in the four most northern regions in Sweden (North). Base category is the center/middle of Sweden, where approximately $80 \%$ of the Swedish population resides. Based on historical events and values, the support for the Sweden Democrats is expected to be excessively large in the very south of Sweden and comparatively low in the northern regions. See Fig. 3 in "Appendix" for geographical division of these dummies. Based on previous literature on radical right and populist support, a set of control variables are included in the analysis. The independent variables are presented and described in Table 1.

\section{Descriptive statistics}

Descriptive statistics is presented in Table 2.

In Table 2, we can see that the support for the Sweden Democrats is higher among respondents in non-urban areas than in urban areas. Average growth in population density in the municipality varies substantially between urban and non-urban regions. Average public service supply (principal component) is lower in non-urban municipalities. Except for fire and rescue services, the share of residents working in public services is lower in non-urban areas. Income and education are on average higher in urban areas than in non-urban areas. While mean share of immigrants is substantially higher in urban municipalities, non-urban municipalities have received a higher percentage of refugees 2010-2014. The urbanization proxies (urban dummy

\footnotetext{
12 The variable growth in population density is sometimes referred to as simply population growth, as these measures coincide for fixed areas, i.e., Swedish municipalities.
} 
Table 1 Variables and definitions

\begin{tabular}{|c|c|}
\hline Variables & Description \\
\hline \multicolumn{2}{|l|}{ Dependent variable } \\
\hline Sweden Democrat support & $\begin{array}{l}\text { Dummy }=1 \text { if the individual vote for the Sweden Democrats in the } \\
\text { national election } 2014\end{array}$ \\
\hline \multicolumn{2}{|l|}{ Regional variables } \\
\hline Urban dummy & Dummy $=1$ if municipality is categorized as urban \\
\hline Growth in population density & $\begin{array}{l}\text { The percentage growth in population density in the municipality } \\
\text { between } 2006 \text { and } 2010\end{array}$ \\
\hline Public services comp & $\begin{array}{l}\text { Principal component of share of the municipal population that } \\
\text { works in school, health care, police and fire and rescue sectors }\end{array}$ \\
\hline Fire and rescue service $\%$ & $\begin{array}{l}\text { The share of the municipal population working in fire and rescue } \\
\text { services }\end{array}$ \\
\hline Police sector \% & The share of the municipal population working in the police sector \\
\hline Preschool and elementary school \% & $\begin{array}{l}\text { The share of the municipal population working in preschools and } \\
\text { elementary schools }\end{array}$ \\
\hline Primary health care $\%$ & $\begin{array}{l}\text { The share of the municipal population working in primary health } \\
\text { care services }\end{array}$ \\
\hline South & Dummy = 1 if located in Skåne (south of Sweden) \\
\hline Middle & Dummy $=1$ if located in the middle of Sweden (omitted) \\
\hline North & Dummy $=1$ if located in the Northern parts of Sweden \\
\hline Refugee intake & Average municipal refugee intake $2010-2014, \%$ of pop \\
\hline Immigrants, municipality & $\%$ of immigrants in the municipality \\
\hline \multicolumn{2}{|l|}{ Individual characteristics } \\
\hline Male & Dummy $=1$ if gender is male \\
\hline Age & Age of the individual \\
\hline Age2 & Age to the power of 2 \\
\hline Higher education & $\begin{array}{l}\text { Dummy }=1 \text { if the individual has a university/ college diploma } \\
\text { (higher education of at least } 3 \text { years) }\end{array}$ \\
\hline Income & Household income 12 categories \\
\hline Married & Dummy $=1$ if the individual is married \\
\hline Unemployed & Dummy $=1$ if the individual is unemployed \\
\hline Life-satisfaction & Self-perceived life-satisfaction, 4 categories \\
\hline
\end{tabular}

and population growth) and share of immigrants are quite highly correlated $(0.537$ and 0.697 , respectively) in the full sample analysis. ${ }^{13}$

\footnotetext{
13 The urbanization proxies: urban dummy/population growth, are negatively correlated with share of refugee intake $(-0.2814$ and -0.353 , respectively) in the full sample analysis.
} 
Table 2 Descriptive statistics

\begin{tabular}{|c|c|c|c|c|c|c|c|}
\hline Variables & $N$ & Mean & $\begin{array}{l}\text { Mean (urban } \\
\text { municipali- } \\
\text { ties) }\end{array}$ & $\begin{array}{l}\text { Mean (non- } \\
\text { urban munici- } \\
\text { palities) }\end{array}$ & SD & Min & $\operatorname{Max}$ \\
\hline Sweden Democrat support & 5041 & 0.093 & 0.082 & 0.115 & 0.290 & 0.000 & 1.000 \\
\hline Urban dummy & 5041 & 0.666 & - & - & 0.472 & 0.000 & 1.000 \\
\hline $\begin{array}{l}\text { Growth in population } \\
\text { density }\end{array}$ & 5041 & 3.408 & 5.164 & -0.096 & 3.468 & -11.111 & 12.016 \\
\hline Public service component & 5041 & 0.015 & 0.161 & -0.278 & 0.884 & -3.398 & 3.907 \\
\hline Fire and rescue service $\%$ & 5041 & 0.081 & 0.079 & 0.087 & 0.047 & 0.000 & 0.357 \\
\hline Police sector $\%$ & 5041 & 0.297 & 0.364 & 0.162 & 0.217 & 0.000 & 1.162 \\
\hline $\begin{array}{l}\text { Preschool and elementary } \\
\text { school } \%\end{array}$ & 5041 & 3.306 & 3.362 & 3.196 & 0.358 & 2.233 & 4.993 \\
\hline Primary health care $\%$ & 5041 & 0.933 & 1.002 & 0.793 & 0.379 & 0.064 & 2.994 \\
\hline Refugee intake $\%$ & 5041 & 0.261 & 0.218 & 0.347 & 0.216 & 0.005 & 3.186 \\
\hline Immigrants $\%$ & 5041 & 14.896 & 17.818 & 9.066 & 7.690 & 3.080 & 42.699 \\
\hline South & 5041 & 0.119 & 0.130 & 0.099 & 0.324 & 0.000 & 1.000 \\
\hline North & 5041 & 0.099 & 0.086 & 0.124 & 0.298 & 0.000 & 1.000 \\
\hline Male & 5041 & 0.481 & 0.482 & 0.478 & 0.500 & 0.000 & 1.000 \\
\hline Age & 5041 & 52.417 & 50.863 & 55.519 & 16.746 & 18.000 & 85.000 \\
\hline Age2 & 5041 & 3028 & 2870 & 3343 & 1720 & 324 & 7225 \\
\hline Higher education & 5041 & 0.324 & 0.375 & 0.221 & 0.468 & 0.000 & 1.000 \\
\hline Income & 5041 & 5.733 & 6.030 & 5.140 & 2.874 & 1.000 & 12.000 \\
\hline Married & 5041 & 0.519 & 0.503 & 0.551 & 0.500 & 0.000 & 1.000 \\
\hline Unemployed & 5041 & 0.027 & 0.028 & 0.024 & 0.161 & 0.000 & 1.000 \\
\hline Life- satisfaction & 5041 & 3.302 & 3.303 & 3.298 & 0.614 & 1.000 & 4.000 \\
\hline
\end{tabular}

\section{Findings}

The results from the regressions are presented in Tables 3 and 4. The results are presented in odds ratios, and the coefficients are interpreted as follows; an increase in $\chi$ by one unit raises the odds of voting for the Sweden Democrats by $\exp (\beta)$ times. Hence, odds ratios larger than 1 indicate a positive relationship and odds ratios smaller than 1 a negative relationship.

\subsection{Urbanization proxies, public service supply and support for the Sweden Democrats}

In Table 3, the propensity to vote for the Sweden Democrats in 2014 is examined by using two different proxies for urbanization. In Models 1-5, urbanization is proxied by the urban dummy variable and in Models $6-10$ by population growth.

In Model 1, when individual characteristics are not controlled for, if the individual resides in an urban municipality, the odds to vote for the Sweden Democrats decreases by $32.9 \%$ (1-0.671). However, part of this relationship is explained by the 


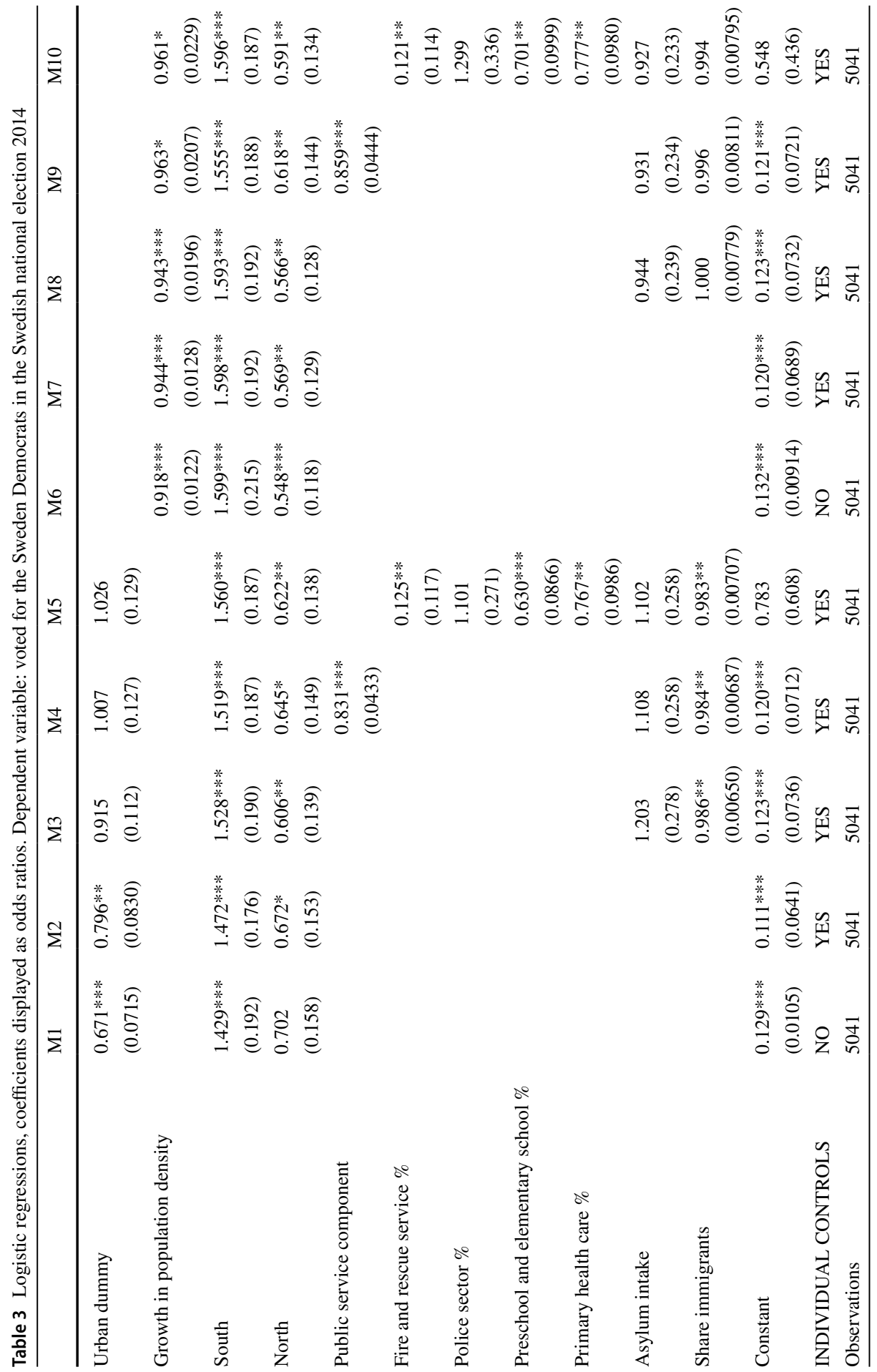




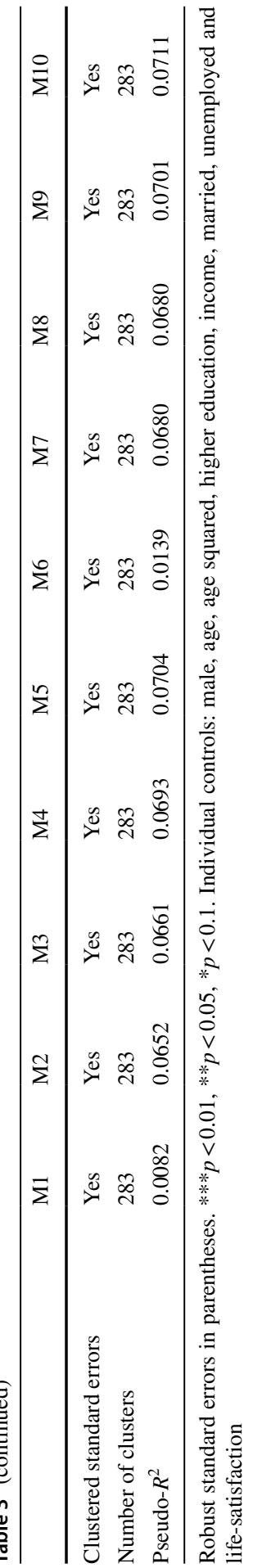


variation in composition of the urban and non-urban populations, i.e., the resident's characteristics. Therefore, in Model 2, when individual (survey respondents') characteristics are considered, this relationship reduces significantly; here, residing in an urban municipality decreases the odds to vote for the Sweden Democrats by $20.4 \%$. The coefficient for the urban dummy is significantly different in Models 1 and 2 (the statistical tests of the difference in coefficients are provided in Table 5 in "Appendix"). Still, more than $50 \%$ of the relationship between urbanization and support for the Sweden Democrats remains and cannot be explained by differences in voter characteristics (resulting from demographic and labor market differences between urban and non-urban regions). Hence, there seem to be additional factors related to urbanization explaining the urban-rural divide in support for the party.

In addition to individual characteristics of the voter, regional characteristics may influence how you vote. The level of immigration in the municipality of residence has been found to correlate with voting behavior in several studies. In Model 3, the two immigration variables are added to the model: share of immigrants in the municipality and asylum intake. Out of the two, the variable on share of immigrants comes out significant: living in a municipality with higher share of immigrants significantly reduces the likelihood of voting for the Sweden Democrats. When immigration is controlled for, the urban dummy coefficient becomes insignificant (the change is statistically significantly-see Table 5 in "Appendix"). These results show that immigration is higher in urban areas and suggest that variations in immigration levels together with variations in residents' characteristics can explain away the binary urban-rural gap in Sweden Democrat support.

In Models 6-10, urbanization is instead proxied by the continuous variable on population density growth. In Model 6, it is clear that individuals living in municipalities that have seen higher population growth are less likely to vote for the Sweden Democrats. The relationship becomes smaller when individual controls are included in the models (i.e., Model 7), yet it remains significant (the difference in the coefficient for population growth estimated with and without individual controls is statistically significant, see Table 5 in "Appendix"). However, when urbanization is proxied by population growth, adding immigration to the model does not diminish the relationship between urbanization and Sweden Democrat support. And in these models, the immigration variables are insignificant (which is in accordance with a large extent of the previous literature). Hence, the relationship between Sweden Democrat support and population growth cannot be explained solely by variations in individual characteristics or immigration. Population growth, i.e., the urban trend (and all that it entails), seems to be a stronger determinant of Sweden Democrat support than urban status or immigration. This is not very surprising as the variable on population growth, in contrast to the urban dummy, captures the dynamics and the attractiveness of the municipality, that is whether the municipality is able to attract individuals and grow, and hence its future prospects.

Next step is to add variables on public service in the models. In Models 4 and 9, the public service principal component is included in the estimations. The public service component is smaller than one and significant in both estimations-indicating that individuals living in municipalities with higher shares of the population working in public services are substantially less likely to vote for the Sweden 
Democrats. The adding of the public service component in Model 9 significantly decreases the relationship between population growth and Sweden Democrat support (see Table 5 in "Appendix") suggesting that public service provision is better in thriving areas and that this phenomenon explains parts of the positive relationship between population growth and Sweden Democrat support. The coefficient for the urban status dummy also changes significantly with the inclusion of public service provision in the model (comparing Models 3 and 4) (see Table 5 in "Appendix"), stays insignificant and is close to one.

In Models 5 and 10, the four public service variables are included instead of their principal component. Individuals residing in municipalities with a larger fire and rescue sector, school sector and health care sector are less likely to vote for the Sweden Democrats. The relationship between the police sector and Sweden Democrat support is positive but insignificant.

The dummy variable for South is significant and robust across models. Individuals who live in the South are more likely to vote for the Sweden Democrats-a finding in accordance with expectations based on history. The dummy for North shows more ambiguous results. The findings on individual factors and far-right populist support are in consensus with most previous research (the coefficients for the individual characteristics are provided in Table 7 in "Appendix"). In consensus with theoretical expectations and previous findings, younger and older individuals, male, unmarried, low-income earners and lower educated individuals show a higher likelihood to vote for the Sweden Democrats. Being unemployed does not significantly relate to support for the Sweden Democrats. Higher life-satisfaction significantly decreases the likelihood to vote for the Sweden Democrats.

\subsection{Urbanization, public service supply and support for the Sweden Democrats: an urban versus non-urban analysis}

The next step is to examine whether urbanization and public service supply is related to support for the Sweden Democrats when urban and non-urban municipalities are analyzed separately. Although the variation is smaller, non-urban and urban municipalities still differ quite extensively in population growth and presence of public services, resulting in a variation in propensity to vote for the Sweden Democrats within these categories as well. In Table 4, population growth is used as a proxy for urbanization and the non-urban sub-sample is analyzed in Models 1-5 and the urban sub-sample in Models 6-10, and the procedure is the same as in Table 3.

First, the relationship between population growth and Sweden Democrat support is estimated without controls (Model 1 and Model 6 for the non-urban and urban sub-samples, respectively). The relationship between population growth and support for the Sweden Democrats is significant on the $1 \%$ level in both the urban and the non-urban analyses. Adding individual characteristics to the model (Models 2 and 7) does not significantly change the coefficient for population growth in the non-urban analysis, but in the urban analysis, individual characteristics explain away parts of the urban trend- Sweden Democrat support relationship (see Table 6 in "Appendix" 


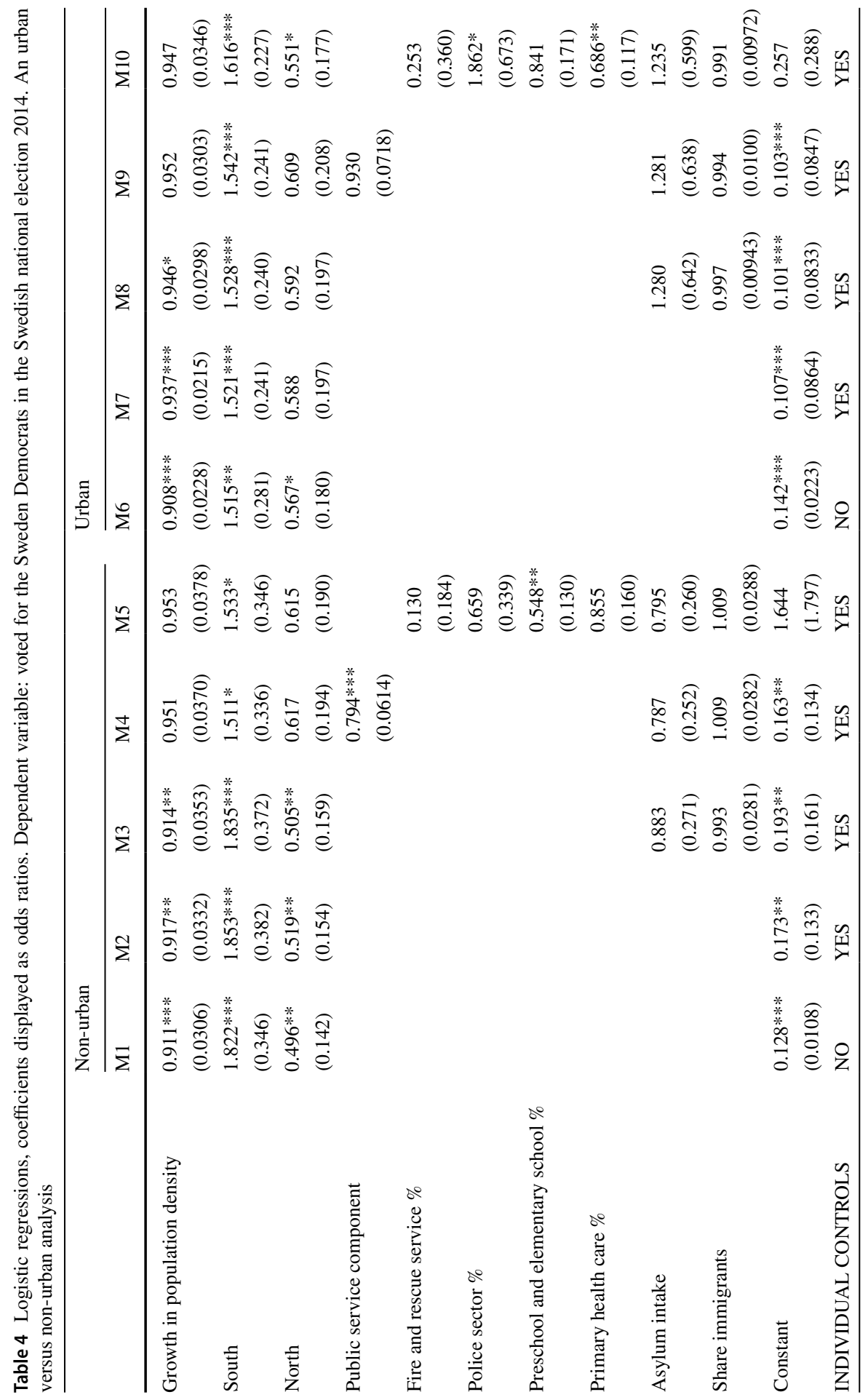




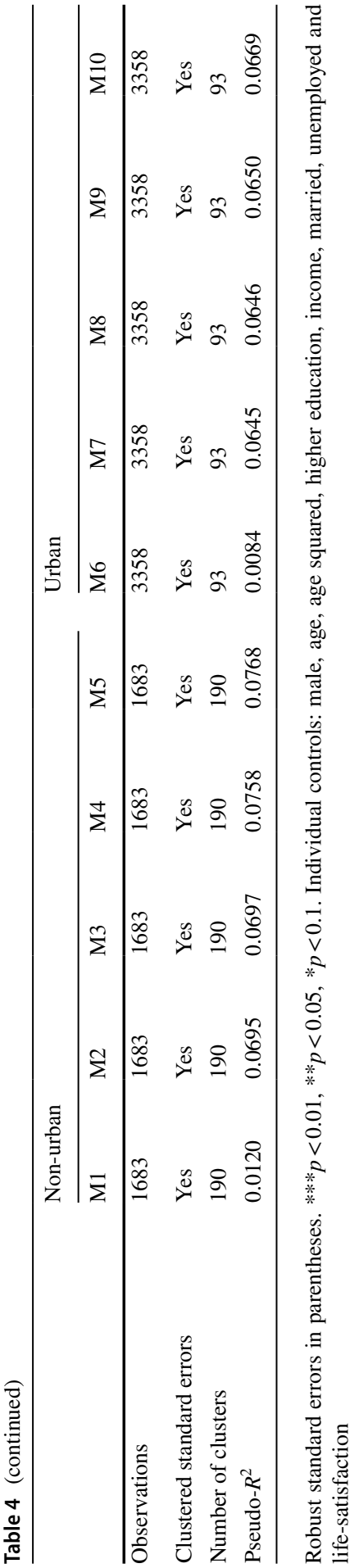


for the statistical tests of differences in coefficients). Immigration variables are added from Models 3 and 8, but both variables are insignificant across estimations.

While the relationship between population growth and Sweden Democrat support is significant in both the urban and non-urban analyses, and when individual controls and immigration are controlled for, the relationship is stronger for non-urban municipalities. A one $\%$ increase in growth in population density in a non-urban municipality decreases the odds of voting for the Sweden Democrats by $8.6 \%(5.4 \%$ in the urban analysis), and if population growth in the non-urban population density increases by $10 \%$, the odds of voting for the Sweden Democrats reduces by $60 \%$ $\left(1-0.914^{10}\right)$. This is a large outcome, and it indicates that there is a substantial variation in voting behavior among non-urban municipalities, where residents in more prosperous non-urban municipalities in terms of population growth are less likely to support the Sweden Democrats. Municipalities that manage to keep their residents, or even grow, are likely to see less of a decline in demand and supply of important public functions and to have stronger labor markets and tax bases. ${ }^{14}$

The next step is to add public service supply to the models (Models 4-5 and 9-10). In the non-urban analysis (Model 4), the coefficient for the public service component is negative and highly significant, indicating that public service provision is one determinant of Sweden Democrat support in non-urban areas. The adding of public service supply also results in an insignificant coefficient for population growth (the difference in coefficients for population growth in Models 3 and 4 is statistically significant on a $1 \%$ level—see Table 6 in "Appendix"). This suggests that public service supply can help explain why Sweden Democrat support vary with population growth among non-urban municipalities, as public service supply appears to be better in municipalities that have seen smaller population decline. In Model 5, the public service sectors are included separately, and it is clear that the results on public service for non-urban areas are driven to large extent by the size of the school sector.

The public service component is not significant in the urban analysis (Model 9), and while the inclusion of the variable results in the coefficient for population growth to become insignificant, the results for population growth do not significantly differ between Models 8 and 9 (see Table 6 in "Appendix"). However, when the public service sectors are included separately (Model 10), significant but contradictory results are found for two of the four public service variables. Individuals in urban municipalities with a larger health care sector are less likely to vote for the Sweden Democrats while individuals who reside in urban municipalities with a larger police sector are more likely to vote for the Sweden Democrats. The latter finding may be driven by exposure to higher criminality.

Considering the control variables, ${ }^{15}$ the results are similar for urban and nonurban municipalities. However, the gender vote gap is even more evident in the urban analysis. Education and income are more strongly related to support for the Sweden Democrats in non-urban areas than in urban areas. A higher education reduces the

\footnotetext{
14 The same analysis can be conducted on urban municipalities-where a net loss of individuals indicate that the municipality is struggling and for some reason (e.g., weak labor markets, less local amenities, etc.) fail to attract individuals - which in turn could lead to political dissatisfaction and support for farright parties, in accordance with theories on protest voting.

15 Results for the control variables are reported in Table 8 in "Appendix."
} 
odds of voting for the Sweden Democrats by $70 \%$ in non-urban areas and by $58 \%$ in urban areas. The largest difference between urban and non-urban municipalities is the relationship between marital status and support for the Sweden Democrats. This relationship is not significant in non-urban municipalities; however, in urban regions being married reduces the odds of voting for the Sweden Democrats by almost $30 \%$. A potential explanation can be derived from the fact that urban areas both have a higher proportion of singles and of immigrants (of which the vast majority are male)-hence the competition on the marriage market is likely to be more anticipated in these municipalities. Furthermore, the higher tendency of Sweden Democrat support among singles is likely to be related to less economic and social stability.

\section{Sensitivity checks}

A few additional analyses have been conducted and are discussed below.

\subsection{Satisfaction with public service and support for the Sweden Democrats}

The relationship between satisfaction with public services and Sweden Democrat support is also examined (see Table 9 in "Appendix"). In this analysis, a variable based on the survey question "How do you think the public service has worked during the last 12 months in the municipality where you live?" with five response categories ranging from "very bad" to "very good" is included. However, the SOM yearly survey consists of four slightly different surveys in 2014 , and only one of them includes this question. Therefore, the estimations in Table 9 involve a restricted sample of 1231 individuals. The coefficient for satisfaction with public services is highly significant in both estimations. Individuals who are more satisfied with the public service in their municipality of residence are less likely to vote for the Sweden Democrats. In these estimations, when self-reported satisfaction with public services is included, neither the urban dummy nor the variable on population growth come out significant.

\subsection{Pooled regression analysis including the election year $\mathbf{2 0 1 0}$}

I also run a pooled regression including the election years 2010 and 2014. The urban-rural divide remains; however, it is not significant in 2010 and including an interaction effect: year dummy * urban dummy shows that the urban-rural divide has increased in size in the 2014 election. Results from these estimations can be obtained from the author upon request.

\section{Conclusion}

The urbanization process generates continuously growing demographic and socioeconomic disparities between urban and non-urban regions. In recent elections (for instance, in the USA, Britain, France and Sweden), substantial differences in voting 
behavior between non-urban and urban regions were evident. This paper investigates the urban-rural divide in support for the Sweden Democrats, the largest farright populist party in Sweden, in the 2014 Swedish election. The paper analyzes how this relationship changes when (1) individual controls, (2) municipal immigration level and trend and (3) municipal provision of public services are considered. The empirical analyses include two urbanization proxies: an urban status variable (dummy) and an urban trend variable (a continuous measure of municipal population growth), survey data on individual characteristics and register data aggregated on municipalities.

The results in this paper show that the urban-rural divide in voting behavior is large and that, nothing else considered, residing in an urban municipality decreases the odds of voting for the Sweden Democrats by 33\%. This gap decreases substantially when voter characteristics are controlled for. Thereby, a large part of the urban-rural divide can be explained by the fact that urban and non-urban populations differ in terms of education, income and other individual characteristics of voters. Adding these voter characteristics, residing in an urban municipality instead of a non-urban/rural municipality still decreases the odds to vote for the Sweden Democrats by $20.4 \%$. This binary urban-rural divide weakens further and becomes insignificant when immigration and public service provision are considered, suggesting that differences in voter characteristics, immigration and public services can explain why the support for the Sweden Democrats varies so much between urban and nonurban regions. The relationship between the continuous urbanization proxy (population growth) and Sweden Democrat support remains significant when individual and municipal factors are controlled for. Hence, in addition to factors commonly discussed in the previous literature (education, income, unemployment, immigration among other things), other factors related to urbanization and its cascade of effects also matter for voting behavior.

Furthermore, results in this paper suggest that public service supply may be one important determinant of the urban-rural gap in far-right support. Residing in a municipality with a higher public service supply significantly decreases the probability of a Sweden Democrat vote. And when availability of, or satisfaction with, public services is considered, the relationship between urbanization and Sweden Democrat support significantly weakens. Examining urban and non-urban municipalities separately displays that the public service component is more strongly associated with far-right support for residents in non-urban municipalities-a result mostly driven by the size of the preschool and elementary school sectors.

Further research needs to be conducted to examine the casual directions more in depth and to better understand the role of regional disparities in the wake of urbanization (i.e., demographic structure and public service supply) on political dissatisfaction and/or voting behavior. Still, the findings in this paper support the hypothesis that individuals who stay in declining non-urban or urban areas with low access to public services are more likely to be dissatisfied with the development of society and thus more likely to respond to the deterioration of their location by voting for a far-right populist party as a protest vote. 


\section{Appendix}

\section{Classification of municipalities as either urban or rural}

The classification is developed by the Board of Agriculture based on data from Statistics Sweden for patterns of intra-municipal commuting, night population and population density. Municipalities are categorized as urban if the population size is at least 30,000 or if the largest urban center has a minimum population of 25,000 inhabitants. Furthermore, smaller municipalities bordering these larger municipalities and where over $50 \%$ of the residents commute to these larger municipalities for work are categorized as urban. The remaining municipalities are classified as non-urban/rural.

See Tables 5, 6, 7, 8, 9 and Fig. 3.

Table 5 Formal tests of the difference in coefficients estimated for the urbanization proxies across models in Table 3

\begin{tabular}{lcc}
\hline Hypothesis & $\chi^{2}$ & Prob $>\chi^{2}$ \\
\hline Urban dummy (Model 1)_Urban dummy (Model 2)=0 & 32.76 & 0.0000 \\
Urban dummy (Model 2)_Urban dummy (Model 3)=0 & 4.97 & 0.0258 \\
Urban dummy (Model 3) -Urban dummy (Model 4)=0 & 5.98 & 0.0145 \\
Pop. Growth (Model 6) -Pop. Growth (Model 7) =0 & 39.31 & 0.0000 \\
Pop. Growth (Model 7) -Pop. Growth (Model 8) $=0$ & 0.00 & 0.9493 \\
Pop. Growth (Model 8)_Pop. Growth (Model 9) $=0$ & 6.49 & 0.0109 \\
\hline
\end{tabular}

Table 6 Formal tests of the difference in coefficients estimated for population growth across models in Table 4

\begin{tabular}{lcc}
\hline Hypothesis & $\chi^{2}$ & Prob $>\chi^{2}$ \\
\hline Non-urban sample & & 0.3623 \\
Pop. Growth (Model 1)_Pop. Growth (Model 2) $=0$ & 0.83 & 0.7896 \\
Pop. Growth (Model 2)_Pop. Growth (Model 3) $=0$ & 0.07 & 0.0067 \\
Pop. Growth (Model 3)_Pop. Growth (Model 4) $=0$ & 7.36 & 0.0006 \\
Urban sample & & 0.6764 \\
Pop. Growth (Model 6)_Pop. Growth (Model 7) $=0$ & 11.86 & 0.3867 \\
Pop. Growth (Model 7)_Pop. Growth (Model 8) $=0$ & 0.17 & 0.75 \\
Pop. Growth (Model 8)-Pop. Growth (Model 9) $=0$ & &
\end{tabular}




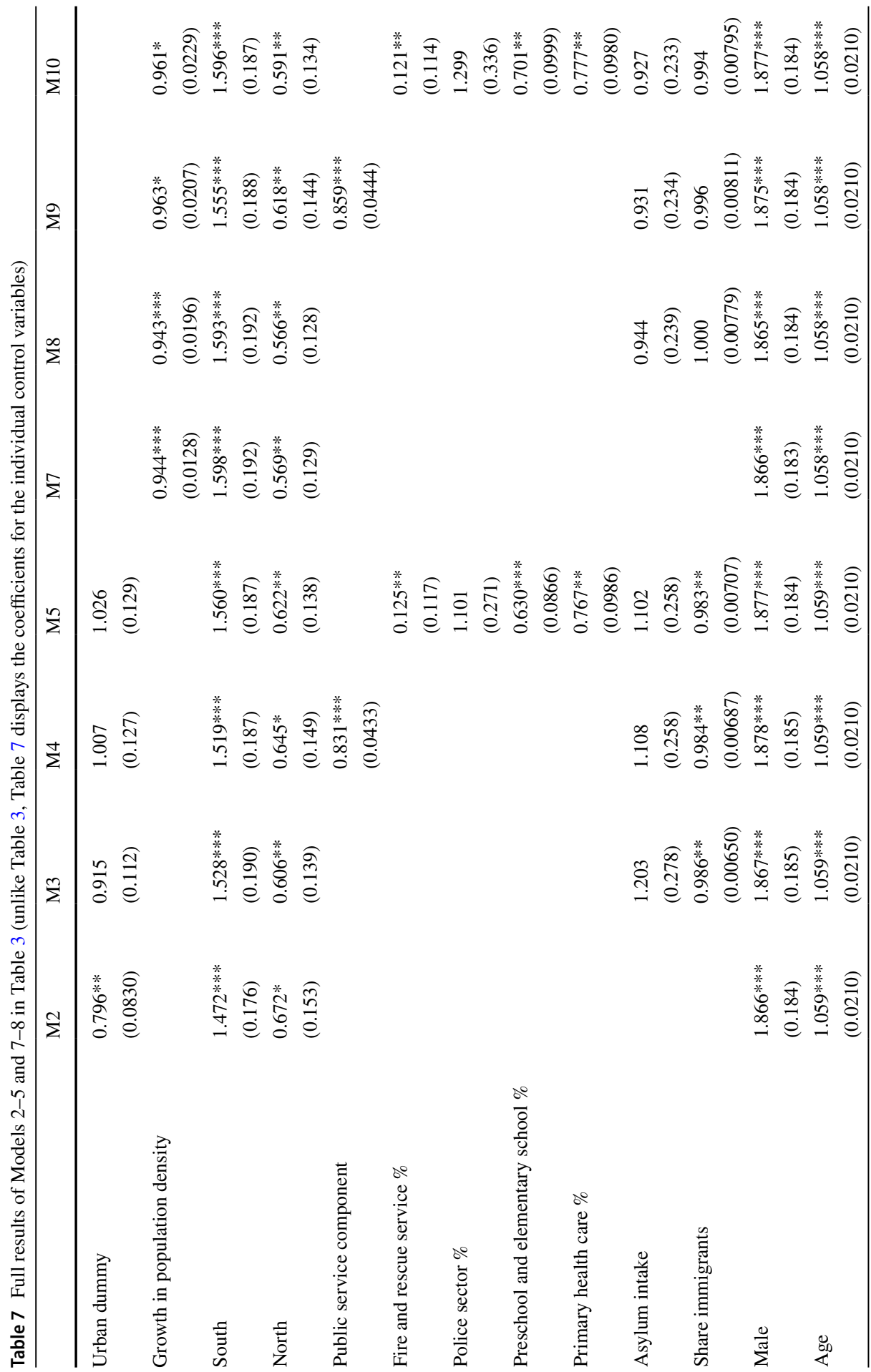




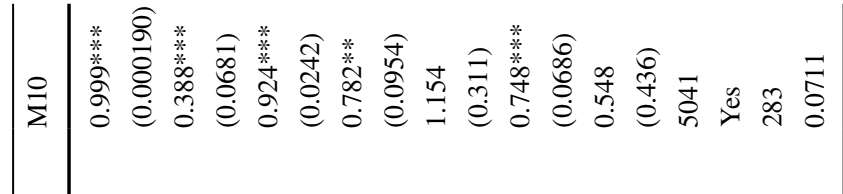

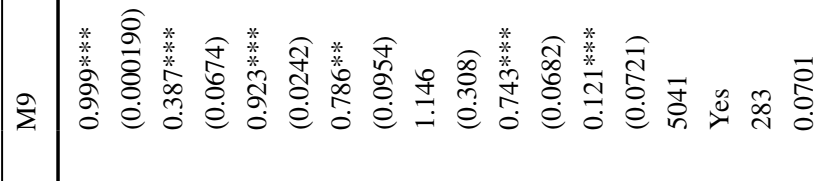

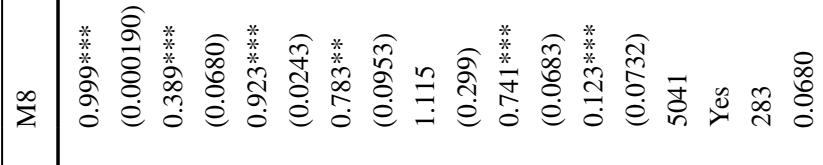

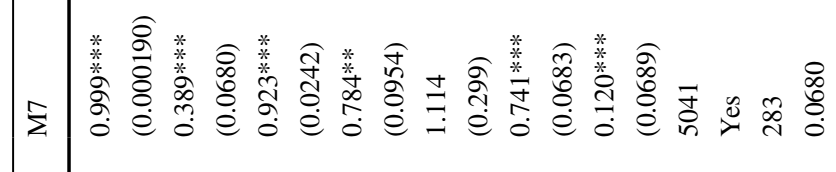

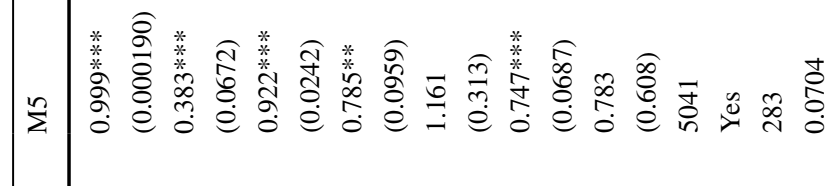

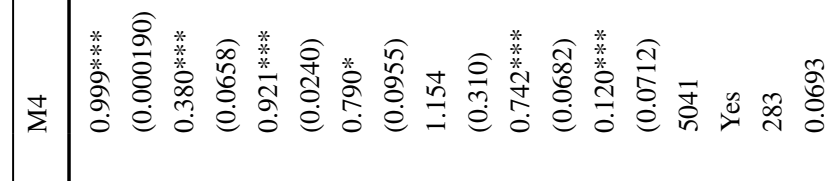

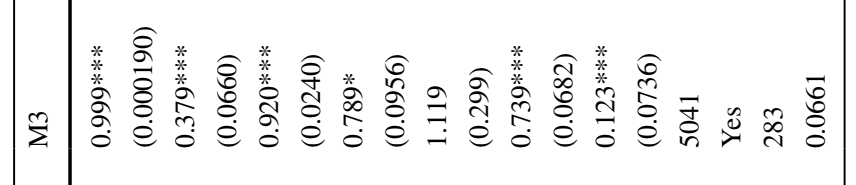

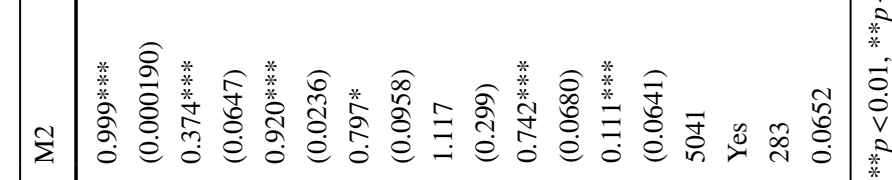

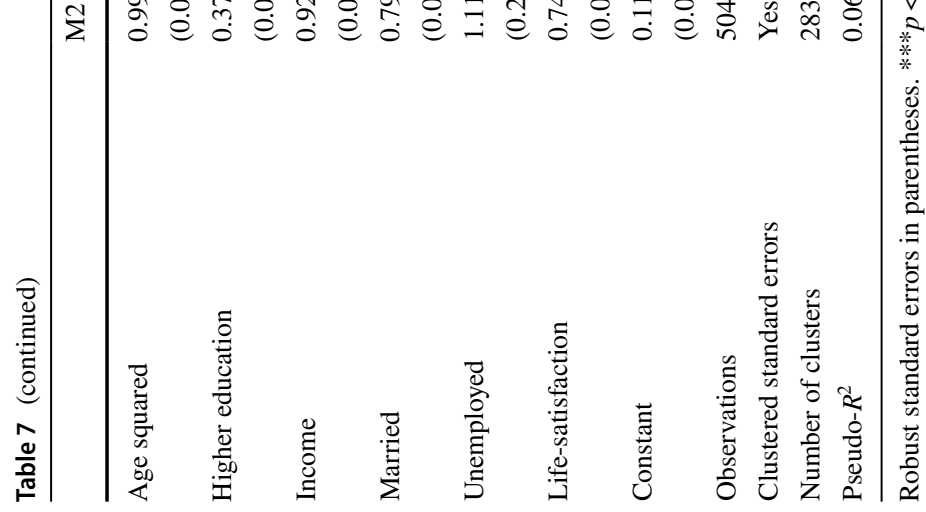




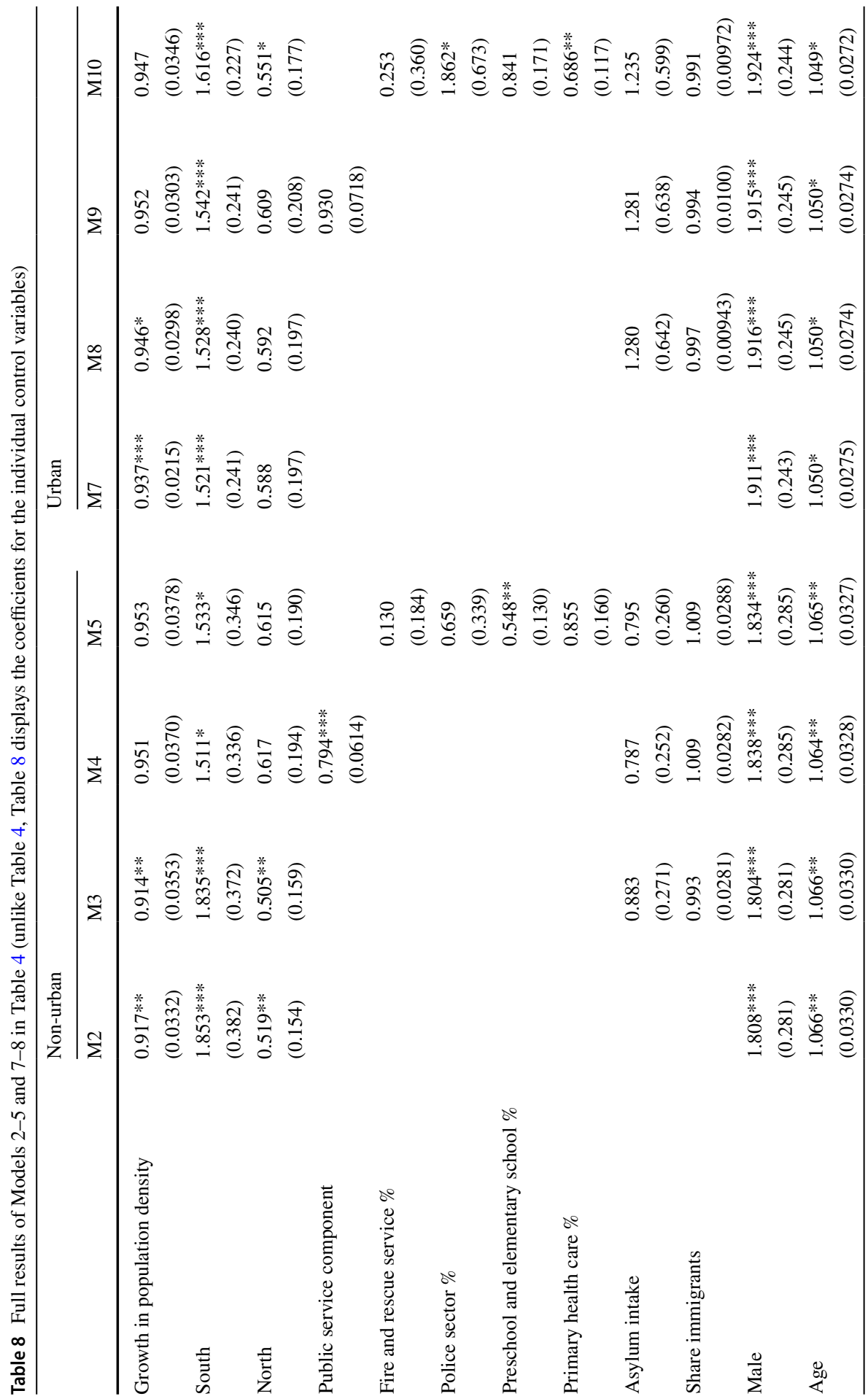




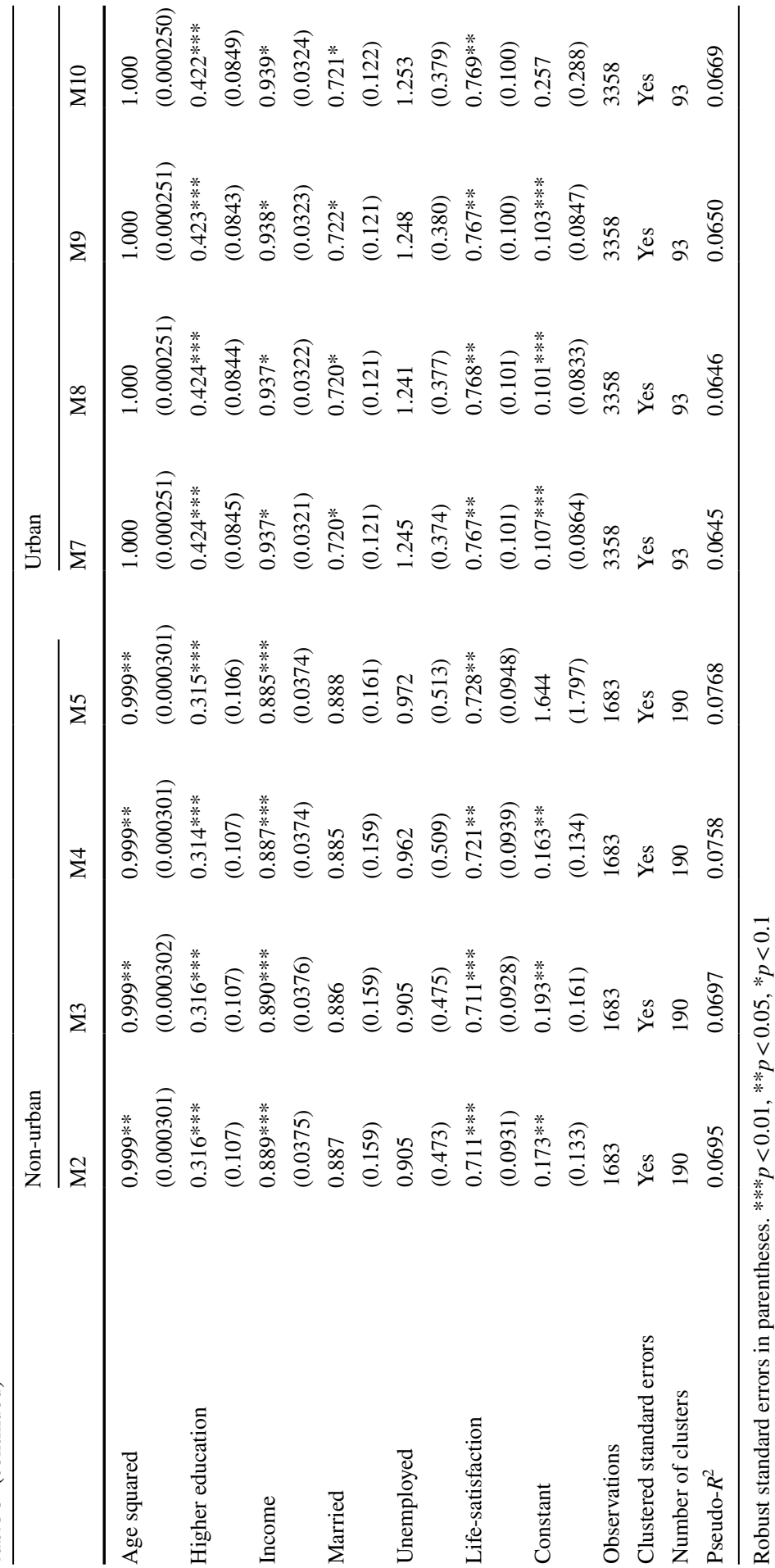


Table 9 Logistic regressions, coefficients displayed as odds ratios. Dependent variable: voted for the Sweden Democrats in the Swedish national election 2014. Restricted sample with survey variables on self-reported satisfaction with public services

\begin{tabular}{lll}
\hline & M1 & M2 \\
\hline Urban dummy & 1.084 & \\
Growth in population density & $(0.325)$ & \\
& & 0.961 \\
South & 0.973 & $(0.0491)$ \\
& $(0.260)$ & 0.994 \\
North & 0.428 & $0.270)$ \\
& $(0.222)$ & $0.430^{*}$ \\
Satisfaction with public service & $0.539 * * *$ & $0.541^{* * *}$ \\
& $(0.0794)$ & $(0.0796)$ \\
Asylum intake & 0.645 & 0.448 \\
& $(0.390)$ & $(0.334)$ \\
Immigrants & 0.983 & 0.998 \\
& $(0.0166)$ & $(0.0204)$ \\
Individual controls & Yes & Yes \\
Constant & 0.164 & 0.176 \\
& $(0.195)$ & $(0.206)$ \\
Observations & 1231 & 1231 \\
Clustered standard errors & Yes & Yes \\
Number of clusters & 243 & 243 \\
Pseudo- $R^{2}$ & 0.0881 & 0.0888 \\
\hline
\end{tabular}

Robust standard errors in parentheses. $* * * p<0.01, * * p<0.05$, ${ }^{*} p<0.1$. Individual controls: male, age, age squared, higher education, income, married, unemployed and life-satisfaction 


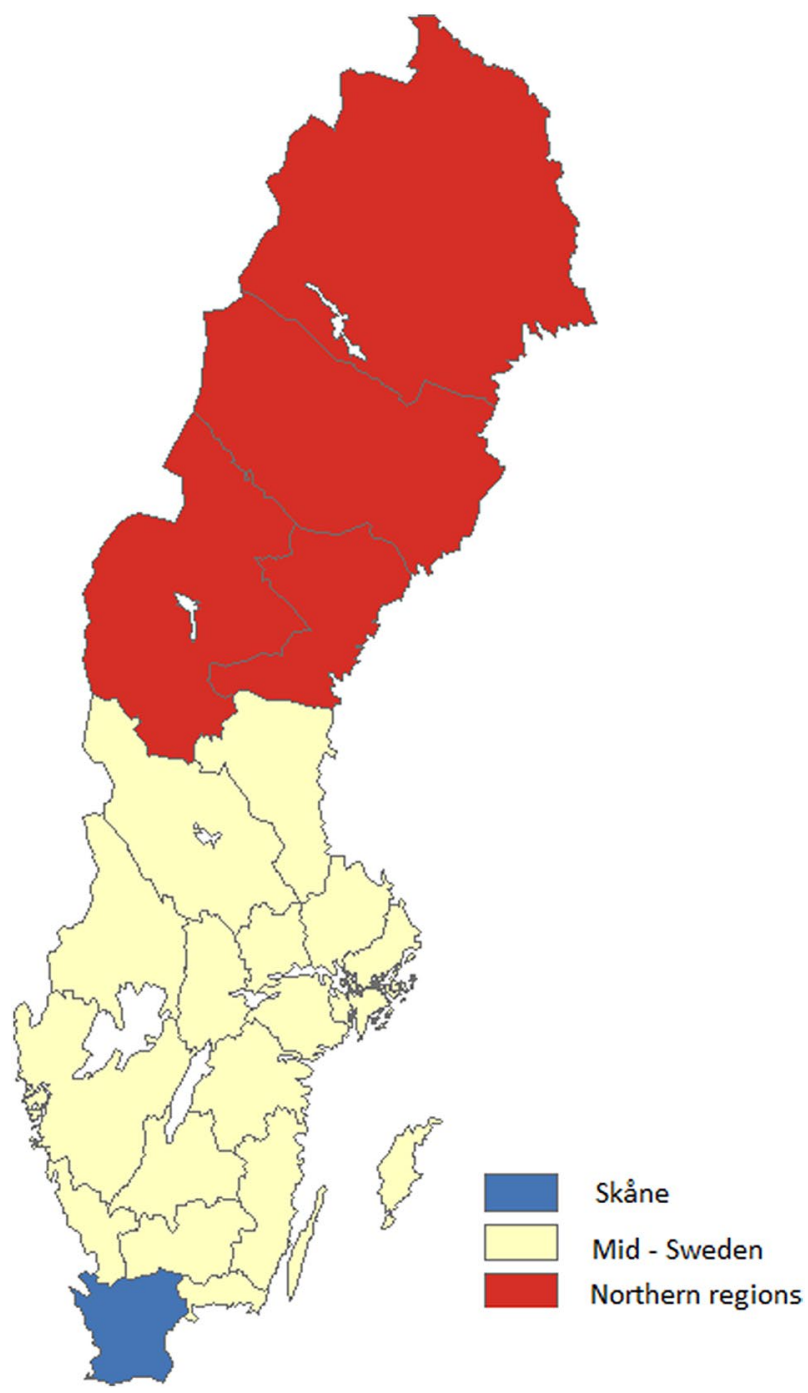

Fig. 3 Division of regional dummies

Acknowledgements The author wants to thank Charlotta Mellander, Sofia Wixe, Johan Klaesson and all participants at the CEnSE and NARSCS seminars for helpful comments and suggestions. I am also very grateful for all valuable comments and constructive suggestions I received during the review process and from the editor, Janet Kohlhase.

Funding Open Access funding provided by Jönköping University.

Open Access This article is licensed under a Creative Commons Attribution 4.0 International License, which permits use, sharing, adaptation, distribution and reproduction in any medium or format, as long as you give appropriate credit to the original author(s) and the source, provide a link to the Creative Commons licence, and indicate if changes were made. The images or other third party material in this article are included in the article's Creative Commons licence, unless indicated otherwise in a credit line to the material. If material is not included in the article's Creative Commons licence and your intended use is 
not permitted by statutory regulation or exceeds the permitted use, you will need to obtain permission directly from the copyright holder. To view a copy of this licence, visit http://creativecommons.org/licen ses/by/4.0/.

\section{References}

Allport GW (1954/1979) The nature of prejudice. Perseus Books, Cambridge

Antonucci L, Horvath L, Kutiyski Y, Krouwel A (2017) The malaise of the squeezed middle: Challenging the narrative of the 'left behind'Brexiter. Compet Change 21(3):211-229

Arkhede S, Oscarsson H (2016) Svenska demokratitrender. SOM-Institutet. https://som.gu.se/digitalAss ets/1648/1648468_28-svenska-demokratitrender-2016.pdf. Accessed 05 Jun 2018

Arzheimer K (2009) Contextual factors and the extreme right vote in Western Europe, 1980-2002. Am J Polit Sci 53(2):259-275

Arzheimer K, Carter E (2006) Political opportunity structures and right-wing extremist party success. Eur J Polit Res 45(3):419-443

Beckett, A. (2017, 2016-12-12). From Trump to Brexit, power has leaked from cities to the countryside. Theguardian.

Belanger S, Pinard M (1991) Ethnic movements and the competition model: some missing links. Am Sociol Rev 56(4):446-457

Bergström P, Dahlberg M, Mörk E (2004) The effects of grants and wages on municipal labour demand. Labour Econ 11(3):315-334

Bjerke L, Mellander C (2016) Moving home again? Never! The locational choices of graduates in Sweden. Ann Reg Sci 59(3):707-729

Coffé H, Heyndels B, Vermeir J (2007) Fertile grounds for extreme right-wing parties: Explaining the Vlaams Blok's electoral success. Elect Stud 26(1):142-155

Cramer, K. J. (2017, 2017-06-19). The great American fallout: how small towns came to resent cities. Theguardian.

Dal Bó E, Finan F, Folke O, Persson T, Rickne J (2018) Economic losers and political winners: Sweden's radical right. Manuscript in preparation

Dehdari, S. (2018). Economic distress and support for far-right parties-evidence from Sweden.

Duranton G, Puga D (2004) Micro-foundations of urban agglomeration economies. In: Henderson V, Thisse F (eds) Handbook of regional and urban economics, vol 4. North-Holland, Amsterdam, pp 2063-2117

Esses VM, Jackson LM, Armstrong TL (1998) Intergroup competition and attitudes toward immigrants and immigration: an instrumental model of group conflict. J Soc Issues 54(4):699-724

Florida R (2002) The rise of the creative class. Wash Mon 34(5):15-25

Ford R, Goodwin MJ (2010) Angry white men: Individual and contextual predictors of support for the British National Party. Polit Stud 58(1):1-25

Gidengil E, Hennigar M, Blais A, Nevitte N (2005) Explaining the gender gap in support for the new right: the case of Canada. Comp Polit Stud 38(10):1171-1195

Glaeser E (2011) Triumph of the city: how our greatest invention makes us richer, smarter, greener, healthier, and happier. Penguin Press, New York

Glaeser E, Kolko J, Saiz A (2001) Consumer city. J Econ Geogr 1(1):27-50

Goodwin M, Milazzo C (2017) Taking back control? Investigating the role of immigration in the 2016 vote for Brexit. Br J Polit Int Relat 19(3):450-464

Gordon IR (2018) In what sense left behind by globalisation? Looking for a less reductionist geography of the populist surge in Europe. Camb J Reg Econ Soc 11(1):95-113

Hirschman AO (1970) Exit, voice, and loyalty: responses to decline in firms, organizations, and states, vol 25. Harvard University Press, Harvard

Hobolt SB (2016) The Brexit vote: a divided nation, a divided continent. J Eur Public Policy 23(9):1259-1277

Hotelling H (1929) Stability in competition. Econ J 39(153):41-57

Ivarsflaten E (2008) What unites right-wing populists in Western Europe? Re-examining grievance mobilization models in seven successful cases. Comp Polit Stud 41(1):3-23

Jacobs J (1969) The economy of cities. Random House, New York 
Karlsson C, Rickardsson J, Wincent J (2019) Diversity, innovation and entrepreneurship: Where are we and where should we go in future studies? Small Bus Econ. https://doi.org/10.1007/S11187-019-00267-1

Kestilä E, Söderlund P (2007) Subnational political opportunity structures and the success of the radical right: evidence from the March 2004 regional elections in France. Eur J Polit Res 46(6):773-796

Klaesson J, Pettersson L (2009) Urban-rural development in Sweden. In: Karlsson C, Andersson A, Cheshire P, Stough R (eds) New directions in regional economic development. Advances in spatial science. Springer, Berlin, Heidelberg, pp 317-330

Lee N, Morris K, Kemeny T (2018) Immobility and the Brexit vote. Camb J Reg Econ Soc 11(1):143-163

Lubbers M, Gijsberts M, Scheepers P (2002) Extreme right-wing voting in Western Europe. Eur J Polit Res 41(3):345-378

Lubbers M, Scheepers P (2002) French Front National voting: a micro and macro perspective. Ethnic Racial Stud 25(1):120-149

Marshall A (1890) Principles of economics, vol 1. Macmillan, London

Mellander C (2013) De ungas flykt till staden

Mellander, C., Öner, Ö., \& Norman, T. (2014, 2014-09-15). Här bor väljarna. Fokus

Oesch D (2008) Explaining workers' support for right-wing populist parties in Western Europe: evidence from Austria, Belgium, France, Norway, and Switzerland. Int Polit Sci Rev 29(3):349-373

Oskarson M, Demker M (2015) Room for realignment: the working-class sympathy for Sweden Democrats. Gov Oppos 50(4):629-651

Politico. (2017, 2017-04-25). French election: as it happened. Politico

Rodríguez-Pose A (2018) The revenge of the places that don't matter (and what to do about it). Camb J Reg Econ Soc 11(1):189-209

Rydgren J (2010) Radical right-wing populism in Denmark and Sweden: explaining party system change and stability. SAIS Rev Int Aff 30(1):57-71

Rydgren J, Ruth P (2011) Voting for the radical right in Swedish municipalities: social marginality and ethnic competition? Scand Polit Stud 34(3):202-225

Rydgren J, Ruth P (2013) Contextual explanations of radical right-wing support in Sweden: Socioeconomic marginalization, group threat, and the halo effect. Ethnic Racial Stud 36(4):711-728

Sherif, M., \& Sherif, C. W. (1953). Groups in harmony and tension; an integration of studies of intergroup relations.

SOM-Institute (2015) Data Collection methods. http://som.gu.se/som_institute/methodology. Accessed 15 Sept 2018

SOU (2015) Demografins regionala utmaningar. Retrieved from https://www.regeringen.se/4ae771/conte ntassets/15c00134b8b4439185d351b14765da2a/demografins-regionala-utmaningar-sou-2015101. Accessed 15 Sept 2018

Strömblad P, Malmberg B (2016) Ethnic segregation and xenophobic party preference: exploring the influence of the presence of visible minorities on local electoral support for the Sweden Democrats. J Urban Aff 38(4):530-545

Sverigedemokraterna (2017, 2017-07-05) Invandringspolitik

The Board of Agriculture (2013) Allt om sysselsättning på landsbygden. http://issuu.com/jordbruksverket /docs/130613074230-e51f1dc79e3949b8873162fb0657a79c/9?e=5119819/3370756. Accessed 15 Sept 2018

Van der Brug W, Fennema M (2007) Causes of voting for the radical right. Int J Public Opin Res 19(4):474-487

Van der Brug W, Fennema M, Tillie J (2000) Anti-immigrant parties in Europe: Ideological or protest vote? Eur J Polit Res 37(1):77-102

Weakliem DL (2002) The effects of education on political opinions: an international study. Int J Public Opin Res 14(2):141-157

Venersdotter F (2015) Den nationella SOM-undersökningen 2014. In: Bergström A, Johansson B, Oscarsson H (eds) Fragment. SOM-institutet, Göterborg

Wennström J, Öner Ö (2015) Den geografiska spridningen av kommunplacerade flyktingar i Sverige. Ekon Debatt 43:52-68

Westinen J (2014) True Finns: A shock for stability? Testing the persistence of electoral geography in volatile elections. Scand Polit Stud 37(2):123-148

Publisher's Note Springer Nature remains neutral with regard to jurisdictional claims in published maps and institutional affiliations. 